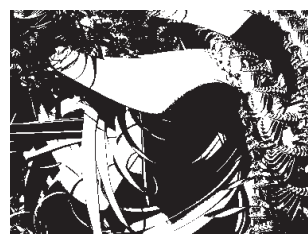

\title{
RELATIONSHIP BETWEEN THE BIG-FIVE PERSONALITY DIMENSIONS AND SPEED OF INFORMATION PROCESSING AMONG ADOLESCENTS
}

Mislav Stjepan ŽEBEC

Centre for Croatian Studies, Zagreb

Diana KOPAČEVIĆ

Faculty of Teacher Education, Zagreb

Boris MLAČIĆ

Institute of Social Sciences Ivo Pilar, Zagreb

UDK: 159.923.35-053.6

Izvorni znanstveni rad

Primljeno: 8. 6. 2009.

A developmental research of the relationship between the Big-Five and speed of information processing (SIP) was conducted with the aim of considering the personality-intelligence relationship.

Personality dimensions were assessed by International Personality Item Pool (IPIP) questionnaire, while SIP and related test errors (Er-SIP) were assessed by Cognitive Abilities (KS2-2) pencil and paper perceptual speed test. The sample consisted of 1063 adolescents (378 males) at the age range from 14 to 18 . The preliminary analyses showed that: (1) age related changes of SIP were weak and those of personality dimensions barely existed, (2) modest gender differences are found for all personality dimensions except for Intellect, and they are not found for SIP and Er-SIP, (3) reduced variability and significant distribution skewness systematically appeared only at Er-SIP, and (4) personality dimensions-SIP relationship was not curvilinear. The main analyses showed that: (1) SIP had low positive correlations only with Extraversion and Agreeableness, (2) Er-SIP didn't correlate with personality dimensions at all and (3) personality dimensions-SIP relationship mostly insignificantly depends on age and gender.

Keywords: The Big-Five personality dimensions, speed of information processing, adolescence, age, gender 
The relationship between personality dimensions and speed of information processing (SIP) is an issue that has not been thoroughly examined yet, despite numerous studies of the relationship between intelligence and personality (Ackerman \& Heggestad, 1997; Chamorro-Premuzic \& Furnham 2004; Demetriou et al., 2003; Eysenck, 1994; Moutafi et al., 2005), and despite the fact that SIP is an important aspect of human intellectual functioning (Carroll, 1993; Danthiir et al., 2005a; Demetriou et al., 2002; Jensen, 2006).

Sočan and Bucik (1998) studied the relationship between SIP, Extraversion and Neuroticism starting with Eysenck's arousal theory (Eysenck, 1967) and the Brebner-Cooper Extraversion model (Brebner, 1980). In addition to individual reaction times measures of SIP, Sočan and Bucik (1998) used three pencil and paper SIP tests and two different Extraversion and Neuroticism questionnaires. The results showed: (1) a modest negative correlation between Extraversion and response time in most of SIP tests; (2) a modest positive correlation only between Neuroticism and decision time in the reaction time test, whereas the correlations between Neuroticism, movement time and all response times in pencil and paper SIP tests were zero; (3) curvilinear correlations between Extraversion scales and response times in SIP tests were not significantly higher than associated linear correlations; (4) only two curvilinear correlations between Neuroticism scales and response speed in SIP tests were significantly higher than associated linear correlations; (5) error rate in different SIP tests was not correlated significantly with any of the Neuroticism scales, and it was correlated significantly with only one Extraversion subscale (Sočan \& Bucik, 1998).

Reeve et al. (2006) analyzed the relationship between personality traits and SIP as a part of a larger study of the relationship between personality, general intelligence $(g)$ and specific dimensions of intelligence. An important aspect of their study was testing the hypothesis that correlations between personality scales and measures of specific intelligence factors change significantly after removing the $g$ variance from them. They used three pencil and paper measures of SIP and ten personality scales, from which they extracted the Big-Five personality dimensions. Among others, the results of their study were: (1) correlations between all five personality dimensions and all three SIP tests were low positive and significant; (2) average correlations between all SIP tests and every personality scale were lower than correlations between cognitive speed factor (Gs) and personality scales; (3) Gs showed the highest correlations with Extraversion, Conscientiousness and Intellect $(0,15<\mathrm{r}<0,19)$; (4) curvilinear correlations between 
DRUŠ. ISTRAŽ. ZAGREB GOD. 20 (2011), BR. 2 (112)

STR. $435-455$

ŽEBEC, M. S., KOPACEVIĆ,'D. MLAČIĆ, B.:

RELATIONSHIP BETWEEN. personality scales and SIP tests did not show any significant difference in regard to linear correlations (Reeve et al., 2006).

Bates and Shieles (2003) examined the relationship between SIP and Openness to experience $(\mathrm{O})$ (from the FFM theory by McCrae \& Costa, 1999) indirectly, by using a crystallized intelligence model (Gc) based on Cattell's investment theory (Schweizer \& Koch, 2002) and found no significant correlation. However, it is important to draw a distinction between Openness to Experience and Intellect factors. The Intellect factor originated from the lexical approach to personality (John \& Srivastava, 1999) and encompasses facets such as perceived intelligence, creativity, imaginativeness, curiosity and reflection. The Openness to Experience factor originated from McCrae \& Costa's FFM (1999) and encompasses facets such as fantasy, aesthetics, feelings, actions, ideas and values. Openness and Intellect are considered as different aspects of a broader personality domain (John \& Srivastava, 1999). It is interesting to note that a recent study (DeYoung et al., 2009) found that Intellect was related with working memory activity and accuracy-related brain activity, while Openness was not.

Stough et al. (1996), Luciano et al. (2004) and Bates and Rock (2004) carried out studies in which personality traits-SIP relationship was indirectly examined by testing the hypothesis that personality and temperament mediate SIP-intelligence relationship (Howe, 1990) and the hypothesis about the curvilinear (i.e. reversed U) Extraversion-intelligence relationship (Robinson, 1989). All three studies used inspection time (IT) as an SIP measure along with various versions of Eysenck's EPQ questionnaire (Eysenck et al., 1985) and clearly refuted Howe's hypothesis. An additional finding was a zero correlation between IT and the assessed personality dimensions. Furthermore, none of the studies confirmed Robinson's hypothesis by using IT as a measure of intellectual ability.

Rindermann and Neubauer (2001) studied SIP-personality relationship with the main purpose of testing the hypothesis that more biologically determined measures of cognitive ability are less personality determined. By using personality scales whose relation to Big-Five dimensions is not known, the authors concluded that the SIP is barely predictable by personality (and mostly by test anxiety, academic self-concept and independence).

Previously mentioned studies point to at least two features in the research of the personality dimensions-SIP relationship: (1) they originate from various theoretical models of the relationship between personality and intellectual functioning and therefore demonstrate that SIP has a place of its own in personality-intellect relationship research; (2) they offer various and inconsistent information about personality dimensions-SIP 
DRUŠ. ISTRAŽ. ZAGREB GOD. 20 (2011),

BR. 2 (112),

STR. 435-455

ŽEBEC, M. S. KOPAČEVIĆ, 'D. MLAČIĆ, B

RELATIONSHIP BETWEEN... relationship, depending on personality scales and SIP measures that were used. The fact that earlier studies did not treat personality dimensions-SIP relationship as a developmental issue illustrates that the analysis of the relationship is still incomplete, despite comprehensive theoretical models of intellect and personality which predict a clear relationship between the former constructs and their developmental dynamics (Demetriou et al., 1999; Demetriou et al., 2003).

Finally, the theoretical model of personality and intellectual functioning that also predicts personality dimensions-SIP relationship and still has not been tested empirically, is Chamorro-Premuzic and Furnham's model (2004), which aims to explain the Big-Five personality dimensions-intelligence relationship using three different levels of intelligence: (1) broad intellectual abilities (i.e. Gf and Gc), (2) IQ tests performance and (3) subjectively assessed intelligence. This model predicts different personality dimensions-SIP relations, depending on the intelligence level we estimate SIP from. If we regard SIP test results as a score in one category of IQ tests, then the model predicts a low positive correlation with Extraversion and a low negative correlation with Neuroticism. If we regard SIP as a significant determinant of primarily ${ }^{1}$ Gf (Danthiir et al., 2005b; Sheppard \& Vernon, 2008), then the model predicts its low negative correlation with Conscientiousness.

When the insufficient and ambiguous empirical findings about the personality dimensions-SIP relationship are taken into account and especially rare findings about age and gender dependence of this relationship, the primary aim of this study is to analyze the relationship between SIP and specific dimensions of the Big-Five personality model (Goldberg, 1990) at the ages ranging from 14 to 18 . Therefore, we aimed to address two problems: (1) to examine the relations between Big-Five personality dimensions and perceptual speed measure of SIP for each of the five age groups and both genders; (2) to find out whether age and gender determine the Big-Five personality dimensions-SIP relationship at the age range from 14 to 18 . The secondary aim of the study is to analyze the results within the framework of a few theoretical models of the personality dimensions-intellectual functioning relationship - by Eysenck (1967), Robinson (1989), Chamorro-Premuzic and Furnham (2004) and Demetriou et al. (2003).

\section{METHOD2}

\section{Participants}

A total of 1063 high school students from two Croatian towns (Zagreb and Trogir) participated in this study. Gender and age structure of the sample is shown in Table 1. 


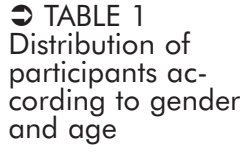

Instruments

\begin{tabular}{lrrr}
\hline & \multicolumn{3}{c}{ Gender } \\
\cline { 2 - 3 } Age & Male & Female & Total \\
\hline 14 & 40 & 71 & 111 \\
15 & 107 & 161 & 268 \\
16 & 97 & 191 & 288 \\
17 & 76 & 171 & 247 \\
18 & 58 & 91 & 149 \\
Total & 378 & 685 & 1063 \\
\hline
\end{tabular}

We used the IPIP 50 Junior $\mathrm{S}$ questionnaire for personality dimensions assessment (Mlačić et al., 2007) and pencil and paper perceptual speed test KS2-2 (Rimac et al., 2006) for SIP assessment.

The IPIP 50 Junior $S$ is a short version of the IPIP 100 (International Personality Item Pool) (Goldberg, 1999) developed for the purposes of measuring the Big-Five dimensions of personality. The analysis of the Croatian version of the IPIP 100 on a sample of students (Mlačić \& Goldberg, 2007) showed clear five factors, with high scale reliability, both in self-reports and in peer-ratings. Moreover, the stability of the five-factor structure of IPIP 50 and satisfactory scale reliability was confirmed in a sample of adolescents in Croatia (Mlačić et al., 2007). Participants responded to each of the IPIP 50 Junior S statements using a 1 to 5 Likert-type scale, ranging from 1 (completely false), over 3 (neither true or false) to 5 (completely true). The IPIP 50 Junior $S$ consists of 10 statements for every factor of the Big-Five model with scale scores for each of the five dimensions: Extraversion, Agreeableness, Conscientiousness, Emotional stability, Intellect.

The perceptual speed test Kognitione sposobnosti [Cognitive Abilities] (KS2-2) is a neutral form of the Lexical version of the Stroop test and consists of 448 words. Fifty per cent of the words are the words "big" while fifty per cent the word "small". All the words are written in lower case letters, and their semantic contents and position is random within the lines and the pages. The participants' task is to cross out as many of the total words "small" as possible in one minute without skipping words or lines. Two test outcomes were used as a test result: the number of words crossed out correctly (SIP) and the number of errors (Er-SIP). The test's discriminability is high because: (1) on average 46 per cent of the target words was crossed out (which is somewhat of a test facility index); (2) variability of the results is considerable $(\mathrm{SD}=15.24 ; \min =59$, $\max =148$ ); (3) distribution of the results is normal (Kolmogo- 
rov-Smirnov $z=1,119 ; p=0,164)$. Content validity is high due to a strong similarity between KS2-2 and pattern recognition perceptual speed measures (Ackerman \& Cianciolo, 2000; Danthiir et al., 2005b).

\section{Procedure}

This study was approved by the Croatian Ministry of Science, Education and Sports and by the principals of the high schools where the research was carried out. The participants gave their consent as well. The testing was conducted collectively in classes of 23 to 30 students, in the morning or the afternoon shifts. Before taking the test the participants were given a short explanation of the purpose of the research and they were provided with arguments motivating their participation. Then the IPIP 50 Junior $S$ was administered during the following ten minutes and the KS2-2 test during the following minute.

\section{RESULTS}

\section{Analysis of the presumptions and determinants of the personality-SIP correlation ${ }^{3}$}

Previous to any SIP-personality correlation analysis, the status of statistic determinants of the two variables relationship has been analyzed: curvilinearity of the relationship, heterogeneous variability, skewness and dependence on a third variable (age and gender).

In order to examine the possible curvilinear relationship between the Big-Five personality dimensions and the two outcomes in the perceptual speed test - SIP and Er-SIP - the regression procedure of curve estimation was applied (whereby $\mathrm{x}=$ personality dimension, $\mathrm{y}=\mathrm{KS} 2-2$ results). Curvilinear relationship is to be found only if the goodness of fit indicator (i.e. $\mathrm{R}^{2}$ between the model and the data) of a linear function is significantly lower than of any other non-linear functions. The results of the curve estimation procedure clearly showed that there is no significant curvilinearity in the relationship of SIP and Er-SIP with the Big-Five personality dimensions in the age groups from 14 to 18 .

By decreasing the variability of the two variables, the probability of higher correlations between them a priori decreases. The variability coefficients (CV) derived from Table $2^{4}$ show the following: (1) the relative variability of personality dimensions is homogenous and of average values ranging from $12 \%$ to $22,5 \%$; (2) the relative variability of SIP is very similar to the variability of personality dimensions; (3) the relative variability of Er-SIP is considerably higher than the others because the extremely high values of the Er-SIP CV are primarily the arti- 
fact of the extremely small average error rate (the absolute variability of this variable is actually the smallest of them all).

\begin{tabular}{|c|c|c|c|c|c|c|}
\hline \multirow[b]{2}{*}{ Variable } & \multirow[b]{2}{*}{ Statistic } & \multicolumn{5}{|c|}{ Age group of the participant } \\
\hline & & 14 & 15 & 16 & 17 & 18 \\
\hline \multirow[t]{2}{*}{ SIP } & $\mathrm{M}$ & 101.7 & 99.5 & 103.4 & 104.7 & 106.2 \\
\hline & SD & 14.78 & 14.86 & 14.70 & 15.20 & 16.22 \\
\hline \multirow[t]{2}{*}{ Er-SIP } & $\mathrm{M}$ & 0.46 & 0.47 & 0.31 & 0.34 & 0.28 \\
\hline & SD & 0.664 & 0.886 & 0.569 & 0.660 & 0.610 \\
\hline \multirow[t]{2}{*}{ Extraversion } & $\mathrm{M}$ & 36.3 & 37.4 & 36.7 & 37.0 & 36.8 \\
\hline & SD & 5.73 & 5.79 & 6.16 & 5.49 & 6.40 \\
\hline \multirow[t]{2}{*}{ Emotional Stability } & $\mathrm{M}$ & 30.9 & 31.7 & 32.0 & 30.7 & 31.2 \\
\hline & SD & 4.35 & 4.38 & 4.46 & 4.61 & 4.39 \\
\hline \multirow[t]{2}{*}{ Intellect } & M & 36.8 & 37.3 & 37.4 & 37.6 & 37.7 \\
\hline & SD & 5.31 & 5.05 & 5.07 & 4.76 & 4.86 \\
\hline \multirow[t]{2}{*}{ Conscientiousness } & $\mathrm{M}$ & 35 & 34.5 & 33.3 & 33.8 & 34.5 \\
\hline & SD & 7.12 & 7.11 & 7.49 & 7.38 & 7.26 \\
\hline \multirow{2}{*}{ Agreeableness } & $\mathrm{M}$ & 41.0 & 40.8 & 40.8 & 41.2 & 41.6 \\
\hline & SD & 5.15 & 5.10 & 5.11 & 4.94 & 5.24 \\
\hline
\end{tabular}

(1) TABLE 2

Descriptive statistics of the SIP test results and personality dimensions that are relevant for interpretation of their correlation
Given that the reverse distribution skewness of the two variables between which Pearson correlation coefficient is calculated a priori reduces that coefficient, we considered the skewness of the perceptual speed and the Big-Five variables. SIP was significantly positively skewed only in the age group of 17. Er-SIP was significantly positively skewed in all the age groups. Conscientiousness and Agreeableness were consistently; while the other personality dimensions were only sporadically negatively skewed (Intellect was not at all).

The age dependence of personality correlations with SIP and Er-SIP might be based on the variability between the age groups means. It was tested using the one-way ANOVA and, where needed, Kruskal-Wallis test. The results of the tests showed significant age related differences for the following personality and SIP variables: (1) Emotional Stability $(\mathrm{F}=2.905, \mathrm{df}=4$, $\mathrm{p}<0.05$; post-hoc test showed significantly lower values at the age of 17 than at 16); (2) SIP $(F=6.287, \mathrm{df}=4, \mathrm{p}<0.015$; post-hoc tests showed that SIP at the age of 15 is significantly lower than SIP at 16, 17 or 18); (3) Er-SIP: Kruskal-Wallis test showed significant decrease $\left(\chi^{2}=9.799 ; \mathrm{df}=4 ; \mathrm{p}=0.044\right)$ from the age of 14 to 18 (see Table 2). Nevertheless, the age related differences noted above explain only 1.1 to $2.3 \%$ of the variance. These different developmental tendencies of personality (stable) and SIP (weakly increasing) to a certain extent justify the analysis of their mutual relationship depending on age.

Similarly, we analyzed the arguments for gender dependence of the Big-Five dimensions-SIP relationship. T-test results showed significant gender differences of the most observed va- 
DRUŠ. ISTRAŽ. ZAGREB GOD. 20 (2011)

BR. 2 (112),

STR. 435-455

ŽEBEC, M. S.

KOPAČEVIĆ, 'D.

MLAČIĆ, B

RELATIONSHIP BETWEEN...

riables: female participants showed higher Extraversion $(t=3.72$, $\mathrm{df}=1038, \mathrm{p}<0.01)$, Conscientiousness $(\mathrm{t}=4.13, \mathrm{df}=1031, \mathrm{p}<0.01)$ and Agreeableness $(t=12.1, d f=682.7, p<0.01)$, while males showed higher Emotional Stability $(\mathrm{t}=5.31, \mathrm{df}=1035, \mathrm{p}<0.01)$. There were no differences with regard to Intellect. On the other hand, female participants showed a slightly higher SIP on the verge of significance $(t=1.98, \mathrm{df}=699.8, \mathrm{p}=0.05)$, with no gender differences with regard to Er-SIP. The considered gender differences show that gender to certain degree is the third variable in the personality dimensions-SIP relationship, except for Intellect.

\section{Analysis of the correlations between the Big-Five personality dimensions and SIP}

Systematic analysis of the Big-Five personality dimensions-SIP relationship at the age from 14 to 18 required the presentation of correlations for every age group, and for the whole sample.

r(SIP-personality)

\begin{tabular}{llcccc} 
Age group & Extraversion & Emotional Stability & Intellect & Conscientiousness & Agreeableness \\
\hline 14 & 0.104 & -0.144 & -0.001 & 0.011 & 0.007 \\
15 & $0.209^{* *}$ & 0.012 & 0.068 & -0.009 & $0.133^{*}$ \\
16 & $0.177^{* *}$ & 0.023 & 0.090 & -0.032 & 0.064 \\
17 & 0.025 & -0.029 & 0.058 & 0.014 & 0.102 \\
18 & 0.121 & -0.029 & 0.115 & 0.153 & 0.131 \\
14 to 18 & $0.129^{* *}$ & -0.023 & $0.076^{*}$ & 0.013 & $0.099^{* *}$
\end{tabular}

(1) TABLE 3

Pearson correlation coefficient between the Big-Five and SIP calculated in the age groups from 14 to 18
Extraversion is a personality dimension which shows the most stable and highest correlation with SIP, despite the fact that it is a low positive correlation. By testing the differences between correlation coefficients of specific age groups and of the whole sample it was established that there was significant difference in the Extraversion-SIP correlation only between the age groups of 15 and $17(z=2.08)$.

Emotional Stability does not correlate with SIP in any of the age groups, or in the whole sample.

Intellect does not correlate with SIP in any of the age groups, while in the whole sample there is a low positive correlation, probably the consequence of significant increase in variability with sample increment. The facts (1) that the correlation obtained for the whole sample is not significantly different from any of the zero correlations in specific age groups (maximal z-statistic of the correlation coefficients difference is $0.90)$ and (2) that the Intellect-SIP correlation in the whole sample explains only $0.6 \%$ of related variance, suggest that SIP and Intellect do not correlate in the adolescent population. 
DRUŠ. ISTRAŽ. ZAGREB GOD. 20 (2011), BR. 2 (112)

STR. 435-455

ŽEBEC, M. S., KOPACEVIĆ,'D. MLAČIĆ, B.:

RELATIONSHIP BETWEEN. .

(1) TABLE 4

Pearson $r$ between the Big-Five personality dimensions and SIP calculated for male and female participants respectively
Conscientiousness does not correlate with SIP in any of the age groups, or in the whole sample of adolescents. Although an underestimation of the correlation might be expected in the age group of $17(\mathrm{r}=0.014 ; \mathrm{p}=0.834 ; \mathrm{N}=242)$, due to a significant and reverse skewness of SIP and Conscientiousness, the calculation of Spearman $r$ s additionally showed that the real correlation most probably is not different from zero $\left(\mathrm{r}_{\mathrm{s}}=0.002 ; \mathrm{p}=0.981 ; \mathrm{N}=242\right.$ ).

Agreeableness also showed a slightly more stable trend of significant correlations with SIP because, in addition to the whole sample-correlation ( $\mathrm{r}=0.099 ; \mathrm{p}=0.001 ; \mathrm{N}=1036)$, it showed even a slightly higher correlation in the age group of $15(\mathrm{r}=0.133$; $\mathrm{p}=0.033 ; \mathrm{N}=259$ ). Reversed and significant skewness of Agreeableness and SIP distributions in the age group of 17 suggested possible underestimation of their correlation $(\mathrm{r}=0.102$; $\mathrm{p}=0.113 ; \mathrm{N}=241$ ), but the calculation of Spearman rs demonstrated that it was not different from zero $\left(\mathrm{r}_{\mathrm{s}}=0.097 ; \mathrm{p}=0.132\right.$; $\mathrm{N}=241$ ). By testing the differences among SIP-Agreeableness correlations related to different age groups and to the whole sample, no difference was established at all (maximal z-statistic of all the differences is $1.10<1.96$ ). Therefore we conclude that the Agreeableness-SIP relationship does not change in the age range from 14 to 18 .

Due to possible threats to other, less important presumptions of Pearson $r$ in the description of the Big-Five dimensions-SIP relationship, Spearman rs corresponding to the correlations in Table 3 was calculated. In the whole sample there was not a single difference between Pearson $r$ and Spearman $r_{s}$, whereas in specific age groups only two differences were found, both in the age group of 16. Namely, Spearman rs was shown to be significant between SIP and Agreeableness ( $r_{s}=0.125 ; p=0.036$; $\mathrm{N}=281$ ) and between SIP and Intellect ( $\mathrm{s}_{\mathrm{s}}=0.121 ; \mathrm{p}=0.045$; $\mathrm{N}=277$ ). Anyway, the first of these rs only confirms the low, positive correlation between SIP and Agreeableness, and the second questions its relation with Intellect.

A systematic analysis of the personality dimensions-SIP relationship also requires calculation of the corresponding correlations for every gender and their comparison.

\begin{tabular}{lccccc} 
& \multicolumn{3}{r}{$r($ SIP-personality) } \\
\cline { 2 - 6 } Gender & Extraversion & Emotional Stability & Intellect & Conscientiousness & Agreeableness \\
\hline Female & $0.098^{*}$ & -0.033 & $0.095^{*}$ & 0.053 & 0.044 \\
Male & $0.164^{* *}$ & 0.023 & 0.054 & -0.074 & $0.135^{* *}$
\end{tabular}

The Table 4 data (1) confirm the positive Extraversion-SIP 
DRUŠ. ISTRAŽ. ZAGREB GOD. 20 (2011), BR. 2 (1 12$)$

STR. 435-455

ŽEBEC, M. S. KOPAČEVIĆ, 'D. MLAČIĆ, B

RELATIONSHIP BETWEEN. low Agreeableness-SIP correlation only for the male adolescents; (3) confirm the zero correlation of SIP with Emotional Stability and Conscientiousness.

The numeric values of the Table 4 correlations show a tendency of slightly higher correlations for the male adolescents, but the testing of gender differences at the three significant correlations didn't confirm it: $\mathrm{z}$ (SIP-Extraversion) $=-1.03$; $\mathrm{z}$ (SIP-Intellect $)=0.63 ; z($ SIP-Agreeableness $)=-1.41$. On the basis of these comparisons and the previous interpretation of Table 4 we conclude that in the age group from 14 to 18 there are no gender differences in the Big-Five dimensions-SIP relationship.

The analysis of possible age and gender differences in personality dimensions-SIP relationship was concluded with partial correlation calculus. Controlling the variable of age in the Big-Five dimensions-SIP relationship yielded correlations almost identical to those without control (the maximum difference between r-s was 0.005). Therefore we can conclude that the personality dimensions-SIP relationship in the developmental period 14 to 18 years of age is not age group specific. On the other hand, the removal of the gender variance from the personality dimensions-SIP relationship reduces the associated correlations somewhat more (the maximum difference between r-s calculated with and without the control of the gender variance was 0.024), so the Intellect-SIP correlation even ceases to be significant ( $\left.\mathrm{r}_{\mathrm{part}}=0.061 ; \mathrm{p}=0.060 ; \mathrm{df}=944\right)$. Nevertheless, the observed decrease in correlations as a consequence of the gender variable control was not significant. Namely, the testing of the differences between the personality dimensions-SIP correlations with and without the control of that variable did not provide any significant difference (maximum Fisher z equals 0.537 in the SIP-Agreeableness relationship).

\section{Analysis of the correlations between the Big-Five personality dimensions and the error rate}

In contrast to SIP that showed low but significant positive correlations with two (eventually three) personality dimensions for the whole sample and for a certain number of age and gender subsamples, Er-SIP was not significantly correlated with any of the personality dimensions. In the whole sample the correlations were in range from $0.001(\mathrm{p}=0.970 ; \mathrm{N}=1037)$ for the Agreeableness-Er-SIP relationship, to $0.049(p=0.111 ; N=1037)$ for the Emotional Stability-Er-SIP relationship. When observing these correlations in specific age groups, their values range from $0.008(\mathrm{p}=0.897 ; \mathrm{N}=242$; age 17) for the Extraversion-Er-SIP relationship, to $0.132(\mathrm{p}=0.114 ; \mathrm{N}=145$; age 18$)$ for the Agreeableness-Er-SIP relationship. In the gender subsamples insignificant correlations range from $0.008(p=0.840 ; N=669$; 
DRUŠ. ISTRAŽ. ZAGREB GOD. 20 (2011), BR. 2 (112)

STR. $435-455$

ŽEBEC, M. S., MLAČIĆ, B.:

RELATIONSHIP BETWEEN. KOPACEVIĆ,'D.

females) for the Agreeableness-Er-SIP relationship to 0.054 $(p=0.165 ; N=670$; females) for the Conscientiousness-Er-SIP relationship. Although the previous skewness analysis of Er-SIP and personality dimensions distributions suggests possible underestimation of a larger number of the associated correlations, the subsequent calculation of Spearman rs showed that the correlation in those cases remains statistically insignificant. ${ }^{5} \mathrm{~A}$ more probable limitation in reaching higher personality dimensions-Er-SIP correlations is the mentioned low variability of Er-SIP, which is the consequence of low error rates in the speed tests. However, Sočan and Bucik (1998) calculated the correlation between the error rate in a perceptual speed test with personality dimensions and obtained the correlation $r=0.23, p<0.03$ for one of the Extraversion subdimensions.

\section{Testing of the reversed U-relationship between SIP-Extraversion and SIP-Emotional Stability}

Although previous regression curvilinearity testing of the personality dimensions-SIP relationship established no sign of curvilinearity that would indicate reversed U-relationship between SIP and Extraversion or Emotional Stability, additional and more conventional testing of that relationship was made by using ANOVA. SIP was considered the dependent variable, while low, average and high Extraversion and Emotional Stability were considered as three levels of the independent variable, determined by z-values calculated in the whole sample of participants $(\mathrm{z}<-1=$ low level; $-1 \leq \mathrm{z} \leq+1=$ average level; $\mathrm{z}>1=$ high level).

\footnotetext{
- TABLE 5 Basic descriptive statistics of SIP for different levels of Extraversion and Emotional Stability calculated in the age group from 14 to 18 years of age
}

\begin{tabular}{llllr}
\hline & & \multicolumn{3}{c}{ SIP statistics } \\
\cline { 3 - 5 } & & $\mathrm{N}$ & $\mathrm{M}$ & $\mathrm{SD}$ \\
\hline \multirow{2}{*}{ Extraversion } & low & 155 & 101,1 & 15,96 \\
& average & 702 & 102,9 & 15,15 \\
\multirow{2}{*}{ Emotional Stability } & high & 182 & 105,0 & 14,29 \\
& low & 136 & 103,7 & 15,78 \\
& average & 706 & 102,9 & 15,18 \\
& high & 194 & 102,2 & 15,24
\end{tabular}

The means show a trend of a constant growth of SIP with the increase of Extraversion, but the trend is on the verge of significance $(\mathrm{F}=2.894 ; \mathrm{df}=2 ; \mathrm{p}=0.056)$, while there are no SIP changes connected with the increase of Emotional Stability $(F=0,383 ; d f=2 ; p=0,682)$. These findings clearly refute a reversed U-relationship between SIP and the two observed per- 


\section{DISCUSSION}

The empirical analysis of the personality dimensions-SIP relationship regarding the gender and the developmental frame of adolescence

The Extraversion-SIP correlation turned out to be the most stable and the highest of all the correlations between SIP and personality dimensions, although low. It indicates that extraverts are a bit better performing the perceptual speed test than introverts, more pronounced in the sample of male than female adolescents. Additionally, this type of Extraversion-SIP relationship was noted in the whole sample of participants and in the subsamples of 15 and 16 years of age so we can say that it is mostly present in the adolescent population. The highest relationship between SIP and Extraversion could stem from the nature of SIP tasks in this research which are motorically demanding. Sočan and Bucik (1998) report that Brebner's predictions say that extraverts tend to demonstrate fast and frequent motor reactions. Although motor mobility in this research is not specifically measured, it can be assumed this is the core of the Extraversion-SIP correlation. A secondary cause of the obtained correlation is Eysenck's (1967) prediction of higher extraverts results in exterior conditions of heightened arousal, which are to a certain extent present in our research due to the competitive atmosphere of testing in groups and the optimal time of the day for the testing. These findings are consistent with the ones of Reeve et al. (2006) and they slightly vary from the results provided by Sočan and Bucik (1998), which got correlations of the same sign, although somewhat higher. However, the findings are clearly different from the zero correlation in the research of Stough et al. (1996), Luciano et al. (2004) and Bates and Rock (2004), probably due to an essential difference of the SIP measures. On the other hand, the refutation of the Extraversion-SIP reverse U-relationship in that research is consistent with our findings.

The correlation of SIP with Emotional Stability and Conscientiousness equals zero in every observed age group and in the whole sample. In other words, emotionally stable and unstable adolescents, both conscientious and unconscientious, get much the same results in a pencil and paper SIP test. Given that according to Eysenck's theory (1967) the crucial factor for the neurosis occurrence is the interaction between hereditary factors and the amount of stress that the individual was subjected to, it is possible that this testing environment did not induce any great stress for the participants, so that negative Emotional Stability-SIP correlation was not found. Furthermore, the expectation of a low negative correlation be- 
DRUŠ. ISTRAŽ. ZAGREB GOD. 20 (2011), BR. 2 (112)

STR. $435-455$

ŽEBEC, M. S., KOPACEVIĆ,'D. MLAČIĆ, B.:

RELATIONSHIP BETWEEN. tween SIP (as a factor of intelligence) and Neuroticism, set by Chamorro-Premuzic and Furnham (2004) model, also was not confirmed. These facts suggest an interesting conclusion: Neuroticism interferes with those components of intelligence which are not determined by SIP (i.e. parts of attention and working memory processes, the general processes of reasoning and deduction, meta-cognitive processes). Nevertheless, the obtained results are mostly consistent with the findings from the previous research because Sočan and Bucik (1998) did not establish a Neuroticism-SIP relationship in any of the pencil and paper SIP tests, while Stough et al. (1996), Luciano et al. (2004) and Bates and Rock (2004) confirmed these zero correlations by using IT measures of SIP. On the other hand, Reeve et al. (2006) found a correlation between Emotional Stability and three measures of SIP in the range from 0.07 to 0.1 , but believed that the percentage of the explained variance did not indicate any meaningful relationship. Regarding the Conscientiousness-SIP relationship the only comparable research is the one by Reeve et al. (2006), resulting in very low and positive Conscientiousness-Gs correlations, but it is necessary to treat this finding with caution. Namely, the percentage of the explained variance is low $(0.3 \%$ to $1.7 \%)$ and the correlations were of opposite sign to those from research that showed a low negative correlation of Conscientiousness with intelligence, especially with Gf (Chamorro-Premuzic et al., 2004; Moutafi et al., 2004). Finally, theoretical expectations of a low negative Conscientiousness-SIP correlation, suggested by the Chamorro-Premuzic and Furnham (2004), were not confirmed. However, this expectation should be considered with precaution due to the difference between SIP and Gf, despite their significant correlation.

The Intellect-SIP correlation in every specific age group and for male gender was not significant, even though it reaches the significance level in the female $(r=0.095 ; p=0.014)$ and in the whole sample of adolescents $(r=0.076 ; p=0.015)$. However, when we take into account less than $1 \%$ of the variance that these correlations explained, we can conclude that we have not found the Intellect-SIP correlation in the adolescent population. Our results are consistent with the findings of Bates and Shields (2003) and with the research that reports a zero correlation of Intellect with $g$ and Gf (Chamorro-Premuzic et al., 2004; Moutafi et al., 2005), and which further correlate with SIP. On the other hand, the results are partially different from the findings of Reeve et al. (2006) because in that research the significant correlation exists for male and not for female adolescents, but that can be probably attributed to the methodological differences. Concerning the expectations, the results were mainly consistent with those derived from the 
DRUŠ. ISTRAŽ. ZAGREB

BR. 2 (112)

STR. 435-455

ŽEBEC, M. S. KOPACCEVIĆ, D. MLAČIĆ, B.:

RELATIONSHIP BETWEEN... GOD. 20 (2011)

Chamorro-Premuzic and Furnham model (2004) which does not predict the Intellect-Gf correlation. A positive correlation of Intellect as a personality dimension could be probably found with self-estimated intelligence, but that is a hypothesis that requires further research. Additionally, Ashton et al. (2000) report that the correlation of the Openness (similar to Intellect) was the highest with the measures of $\mathrm{Gc}$, and low or nonexistent with the measures of Gf.

The Agreeableness-SIP correlation is a somewhat surprising finding. Namely, we didn't find any theoretical models that predicted a positive correlation between Agreeableness and SIP (or Gf or $g$ ), or any research that reports such a relationship, ${ }^{6}$ and the results of this research indicated that it was present. Namely, Pearson correlation coefficients indicate that SIP correlates very low and significantly with Agreeableness in the whole sample of male adolescents and at the age of 15, while Spearman rank-order correlation indicates an additional correlation between those variables for female adolescents and at the age of 16. Although there is the question of how meaningful correlations that explain merely $1-2 \%$ of the variance are, they are not drastically lower than the one in the Extraversion-SIP relationship and request an explanation in further research.

Testing the differences between gender associated Pearson r-s confirmed that in the sample of adolescents the Big-Five dimensions-SIP relationship is not gender-specific, although there is a tendency of a low positive SIP-Intellect correlation only for female and a low positive SIP-Agreeableness correlation only for male adolescents. In the previous personality dimensions-SIP relationship research the gender differences were not statistically tested so that the obtained results cannot be commented comparatively, but it can be carefully affirmed that they are mostly consistent with the findings of Reeve et al. (2006).

The age dependence analysis of the personality-SIP relationship also shows that those relationships during adolescence are mainly not age dependent. Namely, only the Extraversion-SIP correlation was significantly higher at the age group 15 than at 17. It is difficult to comment the obtained findings comparatively because the previous research of personality dimensions-SIP relationship was not developmental.

\section{The theoretical analysis of the research data on personality dimensions-SIP relationship}

If SIP tasks of applied perceptual speed test can be considered intellectually challenging enough for the consideration of the personality dimensions dependence of the test performance according to Eysenck's theory of Extraversion and Neuroti- 
DRUŠ. ISTRAŽ. ZAGREB GOD. 20 (2011), BR. 2 (112)

STR. $435-455$

ŽEBEC, M. S., KOPACEVIĆ,'D. MLAČIĆ, B.:

RELATIONSHIP BETWEEN. ory only to a certain extent. Namely, this theory predicts that in cases of slightly increased level of external arousal (which prevailed in this research) higher Extraversion is related to slightly higher results in SIP tests with a certain tendency towards the reversed U-relationship. Furthermore, Eysenck's theory predicts a higher error rate for extraverts than for introverts. The results of the conducted research confirmed only a slight increase of SIP with the increase of Extraversion. Moreover, Eysenck's theory of Neuroticism predicts that in conditions which do not generate Neuroticism as a state, such as in our research, emotionally more stable people show only slightly higher SIP with an eventual tendency towards reversed U-relationship and slightly lower error rate. Our research did not confirm any relationship of Emotional Stability with the results in SIP test.

However, Robinson's (1989) hypothesis about reversed U-relationship between Extraversion and intelligence tests performance is even more clearly refuted by the results of the SIP test and that additionally suggests that SIP is not the component of intelligence which is under the curvilinear influence of arousal.

The Chamorro-Premuzic and Furnham (2004) model is partially confirmed if we consider SIP as a specific intelligence test and a measure of Gf at the same time. Namely, the predicted SIP's (1) low positive correlation with Extraversion and nonexistent correlation with Intellect was confirmed, (2) zero correlation with Agreeableness was confirmed partially and (3) low negative correlation with Emotional Stability and Conscientiousness was refuted.

Finally, the obtained results can be commented in relation to the developmental theory of the mind-personality relationship of Demetriou et al. (2003). The theory generally predicts low or zero correlations between SIP and self-estimated personality dimensions because constructs belonging to a different level of mind and personality are involved in the correlations. Furthermore, the research of the hypercognitive system and self-estimated personality traits relationship (Demetriou et al., 1999) suggests very low and positive correlations of SIP with all the Big-Five personality dimensions, except for Emotional Stability (where the correlation should be zero). The results of our study agree relatively well with the predictions of Demetriou et al. and can be considered as a test of the relations between the levels of mind and personality which the authors did not conduct.

There is also a need to repeat this study using more different SIP estimates so that the results could be comparable to various estimates of SIP in different studies. Furthermore, in the forthcoming studies it would be important to apply one 
DRUŠ. ISTRAŽ. ZAGREB GOD. 20 (2011), BR. 2 (112),

STR. 435-455

ŽEBEC, M. S. KOPAČEVIĆ, D. MLAČIĆ, B

RELATIONSHIP BETWEEN.. of the $g$ measures besides the SIP measures so that it can be distinguished what part of the personality dimensions- $g$ relationship is described by the personality dimensions-SIP relationship. Namely, in defining SIP and its importance in the structure of human intellect there is no complete consensus (Danthiir et al., 2005a,b; Žebec, 2004), but all the authors point out that SIP represents the duration time of a cognitive process which occurs during a successful performance of every cognitive or mental task. Therefore, it is important to examine whether and how the duration time of the cognitive process is related to personality dimensions and to extract that relation from the complicated personality-intelligence relationship.

\section{NOTES}

\section{REFERENCES} tions with Gf.

2 Funds for this research were provided by Grant (194-19415587-1530) "Personality dimensions, natural language and cognitive development", from the Ministry of Science, Education and Sports.

${ }^{3}$ Detailed analyses of the presumptions/determinants of the personality-SIP correlation are available from the first author upon request.

4 The order of personality dimensions in the following table is defined by theoretical expectations on the size of SIP-personality dimension correlation, starting with the highest (Extraversion and Emotional Stability).

5 The results of nonparametric correlation analyses between Er-SIP and personality can be provided by the first author upon request.

${ }^{6}$ In the research of Reeve et al. (2006) this relationship is significant due to extremely high statistical power, but because of very low correlations $(0.04<\mathrm{r}<0.11)$ the authors did not consider it to be meaningful.

Ackerman, P. L. \& Cianciolo, A. T. (2000), Cognitive, Perceptual-Speed, and Psychomotor Determinants of Individual Differences During Skill Acquisition. Journal of Experimental Psychology: Applied, 6 (4): 259-290. doi:10.1037//1076-898X.6.4.259

Ackerman, P. L. \& Heggestad, E. D. (1997), Intelligence, Personality, and Interests: Evidence for Overlapping Traits. Psychological Bulletin, 121 (2): 219-245. doi:10.1037/0033-2909.121.2.219

Ashton, M. C., Lee, K., Vernon, P. A. \& Jang, K. (2000), Fluid Intelligence, Crystallized Intelligence, and the Openness/Intellect Factor. Journal of Research in Personality, 34 (2): 198-207. doi:10.1006/jrpe. 1999.2276

Bates, T. C. \& Rock, A. (2004), Personality and Information Processing Speed: Independent Influences on Intelligent Performance. Intelligence, 32 (1): 33-46. doi:10.1016/j.intell.2003.08.002 
DRUŠ. ISTRAŽ. ZAGREB GOD. 20 (2011), BR. 2 (112)

STR. $435-455$

ŽEBEC, M. S., KOPACEVIĆ,'D. MLAČIĆ, B.:

RELATIONSHIP BETWEEN...
Bates, T. C. \& Shieles, A. (2003), Crystallized Intelligence as a Product of Speed and Drive for Experience: The Relationship of Inspection Time and Openness to g and Gc. Intelligence, 31 (3): 275-287. doi:10. 1016/S0160-2896(02)00176-9

Brebner, J. M. T. (1980), Reaction Time in Personality Theory. In: A. T. Welford (Ed.), Reaction Times (pp. 309-320). London: Academic Press.

Carroll, J. B. (1993), Human Cognitive Abilities: A Survey of Factor-Analytic Studies. Cambridge: Cambridge University Press.

Chamorro-Premuzic, T. \& Furnham, A. (2004), A Possible Model for Understanding the Personality-Intelligence Interface. British Journal of Psychology, 95 (2): 249-264. doi:10.1348/000712604773952458

Chamorro-Premuzic, T., Furnham, A. \& Moutafi, J. (2004), The Relationship between Estimated and Psychometric Personality and Intelligence Scores. Journal of Research in Personality, 38 (5), 505-513. doi:10.1016/j.jrp.2003.10.002

Danthiir, V., Roberts, R. D., Schulze, R. \& Wilhelm, O. (2005a), Mental Speed: On Frameworks, Paradigms, and a Platform for the Future. In: O. Wilhelm \& R. W. Engle (Eds.), Handbook of Understanding and Measuring Intelligence (pp. 27-46). Thousand Oaks, CA: Sage Publications, Inc.

Danthiir, V., Wilhelm, O., Schulze, R. \& Roberts, R. D. (2005b), Factor Structure and Validity of Paper-and-Pencil Measures of Mental Speed: Evidence for a Higher Order Model? Intelligence, 33 (5): 491-514. doi:10.1016/j.intell.2005.03.003

Demetriou, A., Christou, C., Spanoudis, G. \& Platsidou, M. (2002), The Development of Mental Processing: Efficiency, Working Memory, and Thinking. Monographs of the Society for Research in Child Development, Ser. no. 268, 67 (1): VII-VIII. doi:10.1111/1540-5834.671173

Demetriou, A., Kazi, S. \& Georgiou, S. (1999), The Emerging Self: The Convergence of Mind, Personality and Thinking Styles. Developmental Science, 2 (4): 387-409. doi:10.1111/1467-7687.00083

Demetriou, A., Kyriakides, L. \& Avraamidou, C. (2003), The Missing Link in the Relations between Intelligence and Personality. Journal of Research in Personality, 37 (6): 547-581. doi:10.1016/S0092-6566(03) 00048-5

DeYoung, C. G., Shamosh, N. A., Green, A. E., Braver, T. S. \& Gray, J. R. (2009). Intellect as Distinct from Openness: Differences Revealed by fMRI of Working Memory. Journal of Personality and Social Psychology, 97 (5): 883-892. doi:10.1037/a0016615

Eysenck, H. J. (1967), The Biological Basis of Personality. Springfield: Charles C. Thomas.

Eysenck, H. J. (1994), Personality and Intelligence: Psychometric and Experimental Approaches. In. R. J. Sternberg \& P. Ruzgis (Eds.), Personality and Intelligence (pp. 3-31). Cambridge: Cambridge University Press.

Eysenck, S. B. G., Eysenck, H. \& Barrett, P. (1985), A Revised Version of the Psychoticism Scale. Personality and Individual Differences, 6 (1): 21-29. doi:10.1016/0191-8869(85)90026-1

Goldberg, L. R. (1990), An Alternative "Description of Personality": The Big-Five Factor Structure. Journal of Personality and Social Psychology, 59 (6): 1216-1229. doi:10.1037//0022-3514.59.6.1216 
DRUŠ. ISTRAŽ. ZAGREB GOD. 20 (2011), BR. 2 (112),

STR. $435-455$

ŽEBEC, M. S. KOPACCEVIĆ, D. MLAČIĆ, B.:

RELATIONSHIP BETWEEN..
Goldberg, L. R. (1999), A Broad-Bandwidth, Public-Domain, Personality Inventory Measuring the Lower-Level Facets of Several Five-Factor Models. In: I. Mervielde, I. Deary, F. De Fruyt \& F. Ostendorf (Eds.), Personality Psychology in Europe (Vol. 7; pp. 7-28). Tilburg, The Netherlands: Tilburg University Press.

Howe, M. J. (1990), Does Intelligence Exist? The Psychologist: Bulletin of the British Psychological Society, 3 (11): 490-493.

Jensen, A. R. (2006), Clocking the Mind: Mental Chronometry and Individual Differences. Oxford, UK: Elsevier Ltd. doi:10.1016/B978-008044 939-5/50002-1

John, O. P. \& Srivastava, S. (1999), The Big Five Trait Taxonomy: History, Measurement and Theoretical Perspectives. In: L. A. Pervin \& O. P. John (Eds.), Handbook of Personality: Theory and Research (pp. 102-138). New York: NY: Guilford Press.

Luciano, M., Leisser, R., Wright, M. J. \& Martin, N. G. (2004), Personality, Arousal Theory and Relationship to Cognitive Ability as Measured by Inspection Time and IQ. Personality and Individual Differences, 37 (5): 1081-1089. doi:10.1016/j.paid.2003.11.016

McCrae, R. R. \& Costa, P. T. (1999), A Five-Factor Theory of Personality. In: L. A. Pervin \& O. P. John (Eds.), Handbook of Personality Theory and Research (pp. 139-153). New York: Guilford.

Mlačić, B. \& Goldberg, L. R. (2007), An Analysis of a Cross-Cultural Personality Inventory: The IPIP Big-Five Factor Markers in Croatia. Journal of Personality Assessment, 88 (2): 168-177.

Mlačić, B., Milas, G. \& Kratohvil, A., (2007), Adolescent Personality and Self-Esteem - An Analysis of Self-Reports and Parental-Ratings. Društvena istraživanja, 16 (1-2): 213-236.

Moutafi, J., Furnham, A. \& Paltiel, L. (2004), Why is Conscientiousness Negatively Correlated with Intelligence? Personality and Individual Differences, 37 (5): 1013-1022. doi:10.1016/j.paid.2003.11.010

Moutafi, J., Furnham, A. \& Paltiel, L. (2005), Can Personality Factors Predict Intelligence? Personality and Individual Differences, 38 (5): 1021-1033. doi:10.1016/j.paid.2004.06.023

Reeve, C. L., Meyer, R. D. \& Bonaccio, S. (2006). Intelligence-Personality Associations Reconsidered: The Importance of Distinguishing between General and Narrow Dimensions of Intelligence. Intelligence, 34 (4): 387-402. doi:10.1016/j.intell.2005.11.001

Rimac, I., Žebec, M. S. \& Jurić, D. (2006), Verbalna, neobojena papir-olovka verzija Stroop testa - metrijske osobine. [Verbal Uncolored Paper-and-Pencil Version of the Stroop Test - Metric Properties]. In: V. Ćubela Adorić, Z. Penezić, A. Proroković, A. Vulić-Prtorić (Eds.), XV. Dani psihologije u Zadru: Sažeci radova (p. 116), Zadar: Odjel za psihologiju Sveučilišta u Zadru.

Rindermann, H. \& Neubauer, A. C. (2001), The Influence of Personality on Three Aspects of Cognitive Performance: Processing Speed, Intelligence and School Performance. Personality and Individual Differences, 30 (5): 829-842. doi:10.1016/S0191-8869(00)00076-3 
DRUŠ. ISTRAŽ. ZAGREB GOD. 20 (2011), BR. 2 (112)

STR. 435-455

ŽEBEC, M. S., KOPACEVIĆ,'D. MLAČIĆ, B.:

RELATIONSHIP BETWEEN..
Robinson, D. L. (1989), The Neuropsychological Basis of High IQ. International Journal of Neuroscience, 46 (3-4): 209-234. doi:10.3109/0020 7458908986260

Schweizer, K. \& Koch, W. (2001), A Revision of Cattell's Investment Theory: Cognitive Properties Influencing Learning. Learning and Individual Differences, 13 (1): 57-82. doi:10.1016/S1041-6080(02)00062-6

Sheppard, L. D. \& Vernon, P. A. (2008), Intelligence and Speed of Information-Processing: A Review Of 50 Years Of Research. Personality and Individual Differences, 44 (3): 535-551. doi:10.1016/j.paid.2007. 09.015

Sočan, G. \& Bucik, V. (1998), Relationship between Speed of Information-Processing and Two Major Personality Dimensions - Extraversion and Neuroticism. Personality and Individual Differences, 25 (1): 35-48.

Stough, C., Brebner, J., Nettelbeck, T., Cooper, C. J., Bates, T. \& Mangan, G. L. (1996), The Relationship between Intelligence, Personality and Inspection Time. British Journal of Psychology, 87 (2): 255-268. doi:10.1111/j.2044-8295.1996.tb02589.x

Žebec, M. S. (2004), A Contribution to the Analysis of Human Speed of Information Processing: Developmental and Differential Arguments. Društvena istraživanja, 13 (1-2): 267-292.

\section{Odnos između velepetorih dimenzija ličnosti i brzine obradbe podataka kod adolescenata}

Mislav Stjepan ŽEBEC

Hrvatski studiii, Zagreb

Diana KOPAČEVIĆ

Učiteljski fakultet, Zagreb

Boris MLAČIĆ

Institut društvenih znanosti lvo Pilar, Zagreb

U cilju razmatranja odnosa ličnosti i inteligencije na razini njihovih sastavnica provedeno je razvojno istraživanje odnosa velepetorih dimenzija ličnosti i brzine obradbe podataka (BOP). Primjenom upitnika International Personality Item Pool (IPIP) procijenjene su dimenzije ličnosti, a primjenom testa papir-olovka perceptivne brzine Kognitivne sposobnosti (KS2-2) procijenjen je BOP i pripadni broj pogrešaka (Er-BOP). Uzorak je sadržavao 1063 adolescenta (378 muških) od 14 do 18 godina. Uvodne analize rezultata pokazale su da su (1) dobne promjene BOP-a vrlo slabe, a dimenzija ličnosti gotovo nikakve, (2) skromne se spolne razlike javljaju kod svih dimenzija ličnosti osim kod intelekta, ali se ne javljaju kod BOP-a i Er-BOP, (3) smanjeni varijabilitet i značajno odstupanje od simetričnosti raspodjele sustavno postoji samo kod Er-BOP, (4) odnos BOP-a i 
DRUŠ. ISTRAŽ. ZAGREB GOD. 20 (2011)

BR. 2 (1 112$)$

STR. $435-455$

ŽEBEC, M. S. KOPAČEVIĆ, 'D. MLAČIĆ, B.

RELATIONSHIP BETWEEN.. pojedinih dimenzija ličnosti nije zakrivljen. Glavne analize pokazale su da je (1) BOP vrlo niskim pozitivnim korelacijama značajno povezan samo s ekstraverzijom i ugodnošću, da (2) Er-BOP uopće nije povezan s osobinama ličnosti, (3) odnos BOP-dimenzije ličnosti najvećim dijelom ne ovisi značajno o dobi i spolu.

Ključne riječi: velepetore dimenzije ličnosti, brzina obradbe podataka, adolescencija, dob, spol

\section{Big Five-Persönlichkeitsmerkmale im Verhältnis zur Geschwindigkeit der Datenverarbeitung bei Jugendlichen}

Mislav Stjepan ŽEBEC

Kroatische Studien, Zagreb

Diana KOPAČEVIĆ

Fakultät für Lehrerbildung, Zagreb

Boris MLAČIĆ

Ivo Pilar-Institut für Gesellschaftswissenschaften, Zagreb

In diesem Artikel sollte der Bezug zwischen

Persönlichkeitsmerkmalen und Intelligenz untersucht werden, und zwar auf der Ebene ihrer jeweiligen Bestandteile. Zu diesem Zweck führten die Autoren eine Entwicklungsuntersuchung durch, die den Bezug zwischen den Big FivePersönlichkeitsmerkmalen und der Geschwindigkeit der Datenverarbeitung (GdD) sichtbar machen sollte. Zunächst wurde der Fragebogen International Personality Item Pool (IPIP) zur Ermittlung der Persönlichkeitsdimensionen eingesetzt. Danach prüfte man anhand eines Papier-BleistiftTests die Wahrnehmungsgeschwindigkeit der kognitiven Fähigkeiten (KS2-2), aufgrund dessen die Geschwindigkeit der Datenverarbeitung (GdD) und die entsprechende Fehlerzahl (Er-GdD) ermittelt wurden. An der Untersuchung nahmen 1063 Adoleszenten, davon 378 männliche Teilnehmer, im Alter zwischen 14 und 18 Jahren teil. Erste Ergebnisanalysen zeigen: (1) Altersbedingte Unterschiede bei der jeweiligen Geschwindigkeit der Datenverarbeitung sind sehr schwach ausgeprägt, Persönlichkeitsmerkmale fast überhaupt nicht; (2) geringfügige geschlechtsbedingte Unterschiede treten bei sämtlichen Persönlichkeitsmerkmalen auf, der Intellekt ausgenommen - keine Unterschiede gab es hinsichtlich der Geschwindigkeit der Datenverarbeitung (GdD) und der jeweils auftretenden Fehlerzahl (Er-BOP); (3) eine verringerte Variabilität und wesentliche Abweichungen von der Verteilungssymmetrie sind nur bei der Fehlermange (Er-BOP) erkennbar; (4) das Verhältnis zwischen GdD und einzelnen Persönlichkeitsmerkmalen ist nicht verzerrt. Die Hauptanalyse ergab: (1) GdD steht, allerdings in Form 
DRUŠ. ISTRAŽ. ZAGREB GOD. 20 (2011),

BR. 2 (112)

STR. $435-455$

ŽEBEC, M. S.

KOPACEVIC, D.

MLAČIĆ, B.:

RELATIONSHIP BETWEEN. äußerst schwach ausgeprägter Korrelationen, in einem wesentlichen Bezug einzig zu Extrovertiertheit und angenehmem Auftreten; (2) Er-GdD steht in keinerlei Bezug zu Persönlichkeitsmerkmalen; (3) das Verhältnis zwischen GdD und Persönlichkeitsmerkmalen wird größtenteils nicht maßgeblich von Alter und Geschlechts beeinflusst.

Schlüsselbegriffe: Big Five-Persönlichkeitsmerkmale,

Geschwindigkeit der Datenverarbeitung, Adoleszenz, Alter, Geschlecht 